\title{
Tubular tales
}

\section{A. S. Woolf}

Experimental Nephrology: European Journal of Renal Research. Editor-inchief L. G. Fine. Karger. 6/yr. SFr594, $\$ 397$ (institutional); SFr267, \$178.70 (personal).

NEPHROLOGY has ancient roots in the tasting of urine and proceeded by way of morbid anatomy to physiology. More recently, clinicians have attempted to understand common inflammatory diseases such as nephrotic syndrome, in

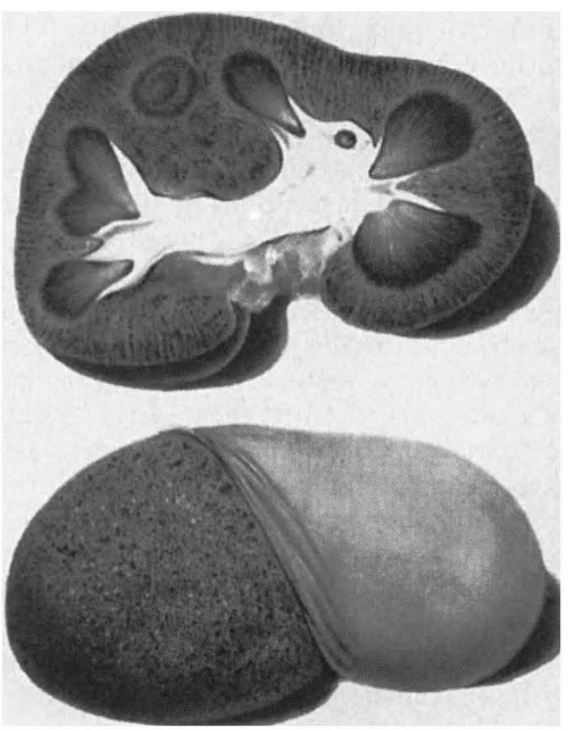

Engraving of human kidney (c.1830).

which massive amounts of albumin leak into the urine. Most advances in this area of immunology were, however, fortuitous and we still have no real idea why corticosteroids are effective in treating the syndrome. In retrospect, the physicians could have used a little help from basic scientists. Today's era of renal research, coinciding with advances in molecular and cell biology, has finally married the disciplines. This year, a mutation that causes multiple renal cysts and kidney failure, one of the commonest inherited diseases in humans, was isolated after a decade of collaboration between clinicians and scientists.

The editor of Experimental Nephrology hopes that the journal will be a forum for European clinicians and scientists who want to understand the mechanisms of kidney diseases. Certainly, a journal devoted to the basic biology of kidney disorders is now needed more than ever, not only to disperse new information from cell and molecular studies but also to counteract the plethora of descriptive clinical reports to be found in established nephrology periodicals. Whether this type of research really needs a uniquely European perspective is debatable, and I hope this editorial angle does not prevent the flow of articles from the rest of the world.

At present, the best features of the journal are the excellent reviews and, so far, the original research articles have been good, although not of the highest standard. Important areas addressed have included transplantation tolerance and the biology and potential therapeutic uses of renal cytokines. Gene therapy, a major challenge in a solid organ like the kidney, has also been highlighted. Recent advances in understanding the genetic basis of renal diseases have not yet been featured. The layout is user-friendly (there are plenty of illustrations, often in colour) and the time between acceptance of articles and publication is reasonable. This is a journal that should be supported on a worldwide basis, not just European.

A. S. Woolf is in the Developmental Biology and Medical Units, Institute of Child Health, 30 Guilford Street, London WCIN IEH, UK.

\section{Hormone cocktail}

\section{Jamshed R. Tata}

Endocrine. Editors P. Michael Conn and Ben Greenstein. Macmillan (UK). 12/yr. $£ 265$ (institutional); $£ 99$ (personal).

THERE was a time when endocrinology was a self-contained discipline, often largely confined to the physiology and biochemistry of endocrine organs. The older journals, such as Endocrinology, Joumal of Endocrinology and Acta Endocrinologica, reflected this emphasis on the site and mechanisms of hormonogenesis. Not so any more. The science of hormones has found its way into an increasingly wide variety of other disciplines of molecular and cell biology, especially membrane biology, neurobiology, cell signalling and gene expression. It explains the remarkable proliferation in the past 10 to 15 years of specialized journals in which hormone research features prominently, such as Molecular Endocrinology, Molecular and Cellular Endocrinology, Journal of Neuroendocrinology, Cellular Signalling, Journal of Receptor Research, Neuroendocrinology and so on. Does the launch of Endocrine (called Endocrine Journal in its first year) represent then a reversal of the trend towards specialist hormoneoriented journals?

Any reversal in Endocrine is more apparent than real. Almost all the topics treated in the first year's issues are covered in the above specialized hormoneorientated journals. For example, 15 original papers in the June 1994 issue deal with receptor gene expression, extracellular matrix, mitogenic response to growth factors, neuroendocrinology, receptor localization, developmental endocrinology, hormone metabolism and intracellu- lar signalling. So there is something for everyone with an interest in the many different aspects of hormonal signalling, a fact also reflected in the make-up of the international editorial board. Who then will benefit from Endocrine? It is unlikely to be the average reader of the traditional endocrinological journals. In their foreword to the first issue of Endocrine, the editors state that they intend to publish papers "on the periphery of endocrinology" as well as "clinical pages with a basic science message". This is certainly true for the first statement, but so far there is not much evidence of the latter.

Apart from original papers, Endocrine also publishes reviews which are of a generally high quality. A unique feature is the appearance from time to time of "Legends in Profile", written by V. C. Medvei. These are brief biographical notes on biologists and clinicians (including such giants as L. Spallanzani, R. de Graaf and T. Addison) who, directly or indirectly, laid the foundations of modern endocrinology. Graduate students should be made to read these. The editors promise that the journal will be "authororientated", which means that they aim to process and publish manuscripts rapidly. The format and appearance of the journal are attractive, although some micrographs and in situ hybridizations would have benefited from colour printing. If the editors and publishers can sustain the present speed and quality of publication, and introduce a cheaper personal subscription rate, then the broad coverage of hormones should ensure that Endocrine has a postnatal period of healthy growth and development.

Jamshed R. Tata is in the Laboratory of Developmental Biochemistry, National Institute for Medical Research, Mill HIII, London NW7 1AA, UK.

\section{Good reception}

\section{R. C. Hughes}

Cell Adhesion and Communication Editors-in-chief Clayton A. Buck and JeanPaul Thiery. Gordon and Breach. 4/yr. ECU572, \$687 (institutional); ECU124, $\$ 149$ (personal).

CELL ADHESION AND COMMUNICATION resembles most closely in appearance and content Molecular Biology of the Cell (formerly Cell Regulation) and Cell Motility and the Cytoskeleton, both of which are well established outlets for papers dealing with receptor-based cellular interactions and cell signalling. There is a close similarity in content too with a large and increasing part of the two main journals of cell biology, Journal of Cell Science and Journal of Cell Biology. Most of the excit- 